\title{
Luxury and the diversity of the Age of Enlightenment
}

E conomic thought of the eighteenth century has often been interpreted as a unitary whole, which set down the foundations of modern economics. In this essay, I discuss how the economic thinking of the era was fragmentary and more diverse than traditional overviews of the subject have suggested. Through a brief analysis of David Hume's essay Of Luxury, published in 1742, I focus on the complex concept of luxury as it was discoursed upon in the eighteenth century. Views of Hume and his contemporaries illustrate the level of disagreement in economic discourse during the eighteenth century, and as a conclusion it seems that diverse and wide-ranging arguments were part of the Age of Enlightenment as a whole.

LATER GENERATIONS HAVE OFTEN TENDED to perceive economic thinking in the eighteenth century as a unitary whole, which manifested in people opposing mercantilism, praising the free market economy, and setting down the foundations of modern economics. It is of course valid to stress these points, which are evident in the classic writings of John Locke, David Hume, François Quesnay and Adam Smith. Besides these generally acknowledged aspects however, less attention has been given to the multiplicity of voices represented in the economic thinking of the eighteenth century. Subjects that aroused plentiful and fierce discussion included, amongst others, questions about the sources of wealth and prosperity, about money and financial markets, and especially about consumption and luxury. The thoughts on the benefits and problems of luxury expressed by David Hume, the most notable philosopher of the Scottish Enlightenment, illustrate the diversity and extent of the thought that made up the eighteenth century Enlightenment.
In his essay 'Of Luxury', published in 1742, Hume discusses his views on the role of luxury. He has generally been seen as an applauder of luxury - which is to say commodities that exceed the scope of basic needs-and the consumer society. In his view, the availability and pursuit of material and luxurious commodities benefit both the individual members of a society and the society as a whole. Jean-Jacques Rousseau and several other contemporaries of Hume were strongly opposed to this sort of thinking, and considered excessive material consumption to be detrimental to human beings. However, Hume did also receive support for his ideas, and hence the vices and virtues of luxury were debated vehemently during the eighteenth century. Views on the topic illustrate the level of disagreement in the discourse of the period, and by studying closely the aforementioned essay, one is able to form an even better picture of it.

First of all, Hume did not himself believe that luxury was absolutely profitable. He makes a difference between 'good' and 'bad' luxury-that is, between the 'refinement of the arts' and 'vicious luxury'-and opts for a happy medium between the two. Hume does not make the assumption that there could be a society completely exempt from vicious luxury, because a small part of the population will always have an opportunity to take their greed to extremes, which is in essence the detrimental exploitation of vicious luxury. Hume does however believe that the moderate consumption of good luxury, which has been restrained by means of good laws, administration and social order, will triumph. Consequently, it is possible to maintain morals and a functioning society with the aid of luxury.

What becomes evident above all in Hume's writing is how profound the economic thought of the Enlightenment was, and how it crosses the bound- 


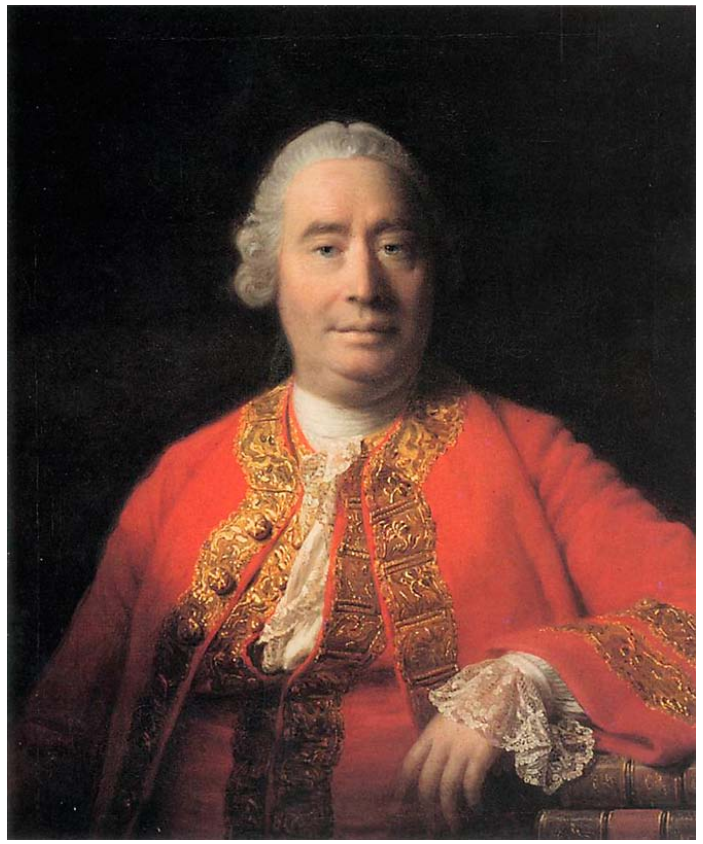

Portrait of David Hume by Allan Ramsay (1713-84). National Gallery of Scotland.

aries of several different subjects. Nowadays, when discussing this thinking, people have tended to emphasise its development into the beginnings of modern economics, which in turn have been described with the aid of appropriate elements of physiocracy and the Scottish Enlightenment-some of them partly detached from their original context. Yet Hume's way of thinking shows how the economic thought of the eighteenth century differed from contemporary economics, which has been mathematicised and systematically defined. Firstly, in contemporary economics the rational maximisation of profit is an axiom, while in Hume's time views on this still differed. Therefore, when debating luxury he has to begin with human nature itself. Hume states that selfish greed and the pursuit of pleasure are basic elements of human nature. In this way, he challenges the 'utility of poverty', which states that apart from their basic needs, the poor do not desire any higher pleasures. They work hard because even the essentials for living are difficult to obtain. In Hume's opinion, it is the opposite situation: all humans desire equally for pleasure, and therefore even the poor proletariat becomes more industrious and eager to work, if it is offered the opportunity to pursue earthly pleasures in the form of luxuries.

Secondly, Hume is compelled to base his argument on ethical thought, which is oftentimes extremely unfamiliar to contemporary economics. The disapproval of luxury in the eighteenth century was to a great extent based on the fear of moral decline, in which earthly splendour dulls the working classes and makes them lazy, crushing the nation's courage and its attempts to attain glory. In this respect too, Hume disagrees completely: above all, luxury strengthens the morale and even sustains its quality, and Hume argues for this with the aid of his statement on the pleasure-seeking aspect of human nature. His third argument in favour of the benefits of luxury Hume bases on historical developments. In his essay 'Of Luxury' he mentions ancient Rome, and states that its downfall was not directly due to the defiling force of luxury, but to inadequate and corrupt administration, and thus, in addition to history, he brings politics into his economic thought. All in all, one can clearly discern from Hume's contemplations of luxury, how the economic thought of the eighteenth century was connected to the study of human nature, as well as to ethics, politics and history. The economy was not at all seen as its own independent field of scientific study (as it is today), but on the contrary was thought to be connected to all human activity.

Even today one should not forget the profound and diverse thoughts on luxury by Hume and his contemporaries. The massive and completely untenable, disposable culture of modern times and the material excess simply demand that we take a critical view of our luxury-centred lifestyles. We do not have to go to extremes in our criticism of consumption, à la Rousseau, as we can do as Hume did, and believe in the benefits of material prosperity if we so wish, but at the same time in our economic thought, we can take into account and critically re-evaluate philosophy, human nature, morals and history.

This sort of healthy and diverse criticism has strengthened my own thinking. Writings from this period that differed from each other made me reconsider the Enlightenment from a new viewpoint. I started to consider the possibility that maybe the eighteenth century was not, in fact, 'the Enlightenment proper', but the commencement of the era. Even though some of the people in the eighteenth century saw themselves as living during the 'period of enlightenment', their views on what defined this era were not congruent with our modern views. In their time, the Enlightenment was in actuality only starting to form into what we now understand it to be. Hence the eighteenth century thinking that emphasised reason and a belief in progress was characterised by hesitancy and conflict, as can be seen from 
the complex views on luxury explored here. Perhaps already in the writing of Immanuel Kant, the Enlightenment had reached in some respects the level that is the closest to our contemporary interpretations. He summed up his views in the following statement: Sapere aude-dare to know. Just as the thinkers during the Enlightenment wanted to free themselves from their authorities, we should likewise free ourselves from the authorities on the history of the eighteenth century and later Enlightenment, who may have defined the eighteenth century and the Enlightenment in too simple and generalising a manner. As it happens, novel and differing interpretations of this era are most welcome.

Translated by Aleksi Mäkilähde.

Niklas Pietilä is student of General History at University of Turku, Finland. E-mail: njtpie(at)utu.fi.

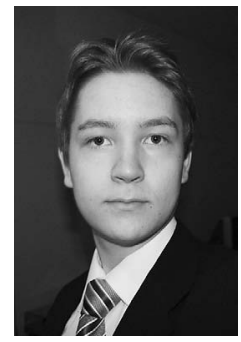

\section{Literature}

Berg, Maxine \& Elizabeth Eger (eds) 2003. Luxury in the Eighteenth Century: Debates, Desires and Delectable Goods. Basingstoke: Palgrave.

Hume Studies published by the Hume Society. http://www.humesociety.org 